Kısa Bilimsel Çalışma / Short Communication

\title{
Bir köpekte medial processus coronoideus kırığı ve operatif sağaltımı
}

\author{
Cenk YARDIMCI, Alper ÇETINKAYA, Arkun CANDAŞ
}

Ankara Üniversitesi Veteriner Fakültesi Cerrahi Anabilim Dalı, Ankara

\begin{abstract}
Özet: Collie ırkı, 7 yaşlı, erkek bir köpekte unilateral medial processus coronoideus kırı̆̆ı tanımlandı. Klinik muayenede kronik topallık ve ağrı, radyolojik muayenede ise medial processus coronoideus kırı̆̆ı ve periartiküler osteofitozis gözlendi. Fragmentin operatif olarak uzaklaştırılmasını izleyen postoperatif kontrol döneminde, ilgili ekstremitede fonksiyonel iyileşme gözlendi.

Anahtar sözcükler: Kırık, köpek, processus coronoideus.
\end{abstract}

\section{Fragmented medial coronoid process and its operative treatment in a dog}

Summary: A unilateral fragmented medial coronoid process was described in a 7-year-old, male Collie. In clinical examination chronic lameness and pain, in radiological examination fragmented medial process and periarticular osteophytosis was observed. At the postoperative control period following operative removal of the fragment, functional improvement of the extremity was observed.

Key words: Dog, fracture, processus coronoideus.

Processus coronoideus, ulna'nın incisura torchlearis'inin distomedialinde yer alıp, caput radii ve medial condylus humeri ile eklemleşir (1). Köpeklerde processus coronoideus'un ossifikasyonu yaklaşık 20-22 haftalıkken tamamlanır (5). Medial processus coronoideus kırı̆ğ ("fragmented medial coronoid process" FMCP) küçük rrklarda da bildirilmesine rağmen, en sık olarak büyük ırk köpeklerde $(2,3)$, \%75 ve daha üzeri siklıkta da erkeklerde gözlenir (3). FMCP'nin en sik gözlendiği ırklar sırasıyla; Rottweiler, Bernese Mountain Dog, Retriever, Newfoundland, German Shepherd ve Chow Chow'lardır (1). FMCP'nin oluşumunda osteokondrozis ve dirsek uyumsuzluğu gibi birbirinden bağımsız iki neden üzerinde durulmaktadır (1).

Çalışma materyalini, Ankara Üniversitesi Veteriner Fakültesi Cerrahi Anabilim Dalı Ortopedi ve Travmatoloji Bilim Dalı Kliniği’ne kronik sol ön ekstremite topallığı şikâyeti ile getirilen 7 yaşlı, 27 kg ağırlığında, Collie 1rk1 erkek bir köpek oluşturdu. Alınan anamnezde, olgunun yaklaşık 6 aydır süren soğuk bir intermittant topallığ olduğu öğrenildi. Olgunun klinik muayenesinde ilgili ekstremitesine yüklenmediği gözlenirken, yürürken hafif sektiği, koşarken ise ilgili ekstremitesini hafif fleksiyonda tutarak hiç kullanmadığı belirlendi. Dirsek eklemine yaptırılan hiperfleksiyon ve hiperekstensiyonda ağrı ve hareket kısıtlanması gözlendi. Radyolojik muayenede her iki dirsek ekleminin, condylus humeri'de olası bir osteochondritis dissecans (OCD) açısından anterioposterior (A/P), FMCP açısından A/P $15^{\circ}$ içe rotasyon (7) ve craniolateral-caudomedial $20^{\circ}$ oblik (4), processus anconeus ayrılması (UAP) açısından ise $85^{\circ}$ fleksiyonda M/L (6) radyografileri alındı. M/L pozisyonda herhangi bir UAP bulgusuna rastlanılmazken, processus anconeus ile olecranon arasındaki bölge ile caput radii'nin cranial ve proksimal eklem kaidesinde periartiküler osteofitozis gözlendi (Şekil 1-A). A/P pozisyonda alınan radyografilerde condylus humeri'de OCD gözlenmezken, epicondylus humeri'nin medial ve lateralinde periartiküler osteofitozis ve FMCP izlendi (Şekil 1-B).

Olgunun genel anestezisi Xylazine $\mathrm{HCl}$ (Alfazyne ${ }^{\circledR}$, $20 \mathrm{mg} / \mathrm{ml}$, Alfasan) premedikasyonu sonrasında uygulanan Ketamin $\mathrm{HCl}$ (Alfamine ${ }^{\circledR}, 100 \mathrm{mg} / \mathrm{ml}$, Alfasan) ile sağlandı. Operasyon bölgesinin traş ve dezenfeksiyonu yapıldıktan sonra hasta operasyon masasına ilgili ekstremitesinin medial yüzü üstte kalacak şekilde, lateral pozisyonda yatırıldı. Epicondylus medialis'in proksimalinden, radius'un proksimal 1/3'üne kadar uzanan 8-10 cm'lik bir deri ensizyonunu takiben deri altı bağ doku ve fascia antebrachii'nin diseksiyonu yapıldı. Musculus pronator teres ile musculus flexor carpi radialis arasından uygulanan küt diseksiyonu (Şekil 2A) takiben ligamentum collaterale mediale'nin altından eklem kapsülü ensize edildi. Daha sonra dirsek eklemine yaptırılan supinasyonu takiben serbestleşmiş olan apikal fragment ince bir hemostatik pens ile yakalandı ve uzaklaştırıldı 

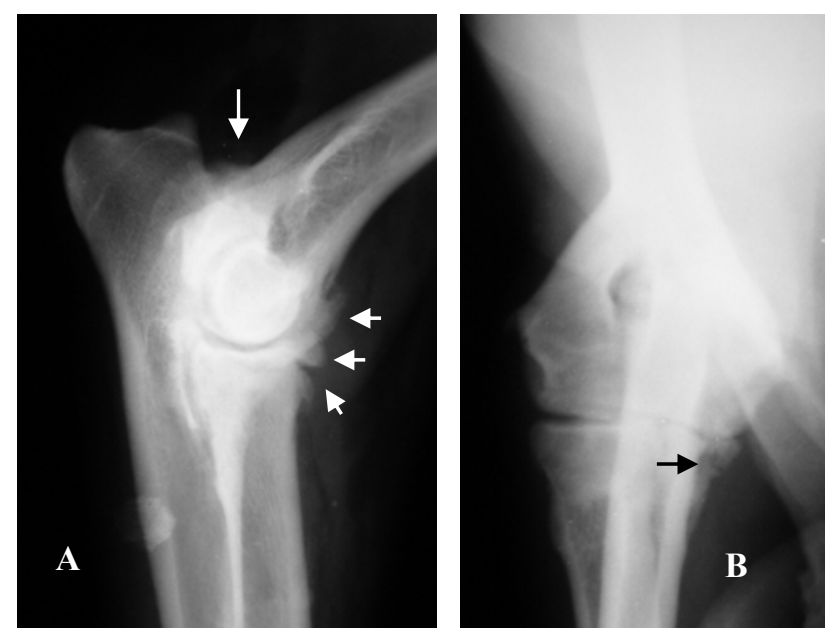

Şekil 1A-B. Olgunun preoperatif M/L (A) ve A/P (B) radyografilerinde periartiküler osteofitozis (oklar) ve FMCP (siyah ok). Figure 1A-B. Periarticular osteophytosis (arrows) and FMCP (black arrow) in $\mathrm{M} / \mathrm{L}$ (A) and $\mathrm{A} / \mathrm{P}$ (B) radiographic views preoperatively
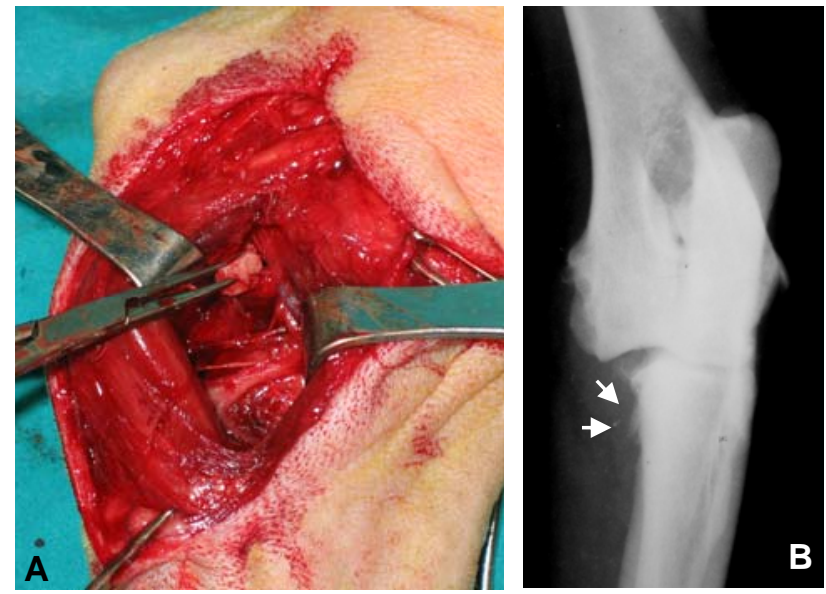

Şekil 2A-B. FMCP'nin (ok) operatif olarak uzaklaştırılması(A) ve postoperatif olarak alınan oblik radyografide(B) operasyon bölgesi (çift ok)

Figure 2A-B. Surgical removal of FMCP (arrow) (A) and operation area (double arrow)in the oblique radiography(B) postoperatively

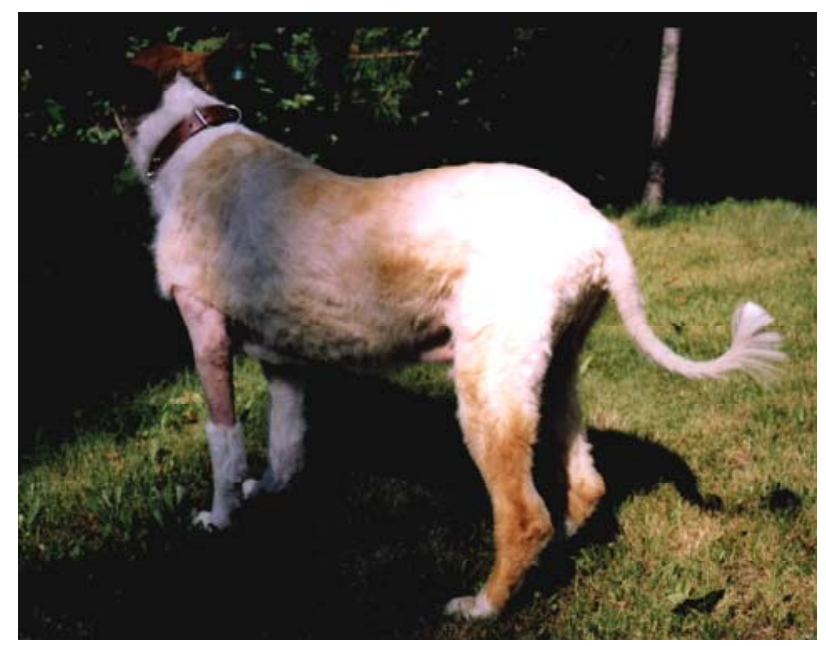

Şekil 3. Olgunun postoperatif 7. gündeki görünümü Figure 3 . View of the case at the $7^{\text {th }}$ day postoperatively
(Şekil 2A). Daha sonra eklem kapsülü, derialtı bağ doku ve deri rutin olarak kapatıldı. Postoperatif kontrol radyografisi alındı (Şekil 2B). Operasyon sonrasında, bölge olası eklem efüzyonunu önlemek ve dikiş hattını korumak amacıyla 5 gün süreyle koruyucu bandaja alındı. Non-steroid antienflamatuar olarak Carprofen (Rimadyl ${ }^{\circledR}$ $50 \mathrm{mg}$ tb, Pfizer) eklemdeki şiddetli kıkırdak lezyonlarına karşı kondroprotektif olarak glikozamin sülfat ve kondroitin sülfat yanında vitamin, mineral ve iz elementler (Arthriti-UM ${ }^{\circledR}$, Mark \& Chappel) desteği kullanıldı. Hasta sahibinden alınan bilgiler doğrultusunda olgunun operasyondan 48 saat sonra ilgili ekstremitesini kullanmaya başladığı öğrenildi. Postoperatif 7. günde yapılan klinik muayenede eklemdeki ilerlemiş olan dejeneratif lezyonlara rağmen, ilgili ekstremitenin normal yürürken ve koşarken fonksiyonel olarak kullanılabildiği gözlendi (Şekil 3).

\section{Kaynaklar}

1. Boulay JP (1998): Fragmented medial coronoid process of the ulna in the dog. Vet Clin North Am Small Anim Pract, 28, 51-75

2. Grondalen J (1981): Arthrosis of elbow joint of young rapidly growing dogs. V. A pathoanatomical investigation. Nord Vet Med, 33, 1-16

3. Lewis PD, Parker RB, Hager DA (1989): Fragmented medial coronoid process of the canine elbow. Compend Contin Educ Pract Vet, 11, 703-716

4. Miyabayashi T, Takiguchi M, Schrader SC (1995): Radiographic anatomy of the medial coronoid process of dogs. J Am Anim Hosp Assoc, 31, 125-132

5. Schulz KS, Krotscheck U (2002): Canine elbow dysplasia. 1927-1952 In: D Slatter (Ed.), Textbook of Small Animal Surgery. WB Saunders Company, Philadelphia.

6. Yardımcı C, Kürüm B (2004): Kangal ırkı bir köpekte unilateral III. derece processus anconeus ayrlması olgusu, IX. Ulusal Veteriner Cerrahi Kongresi. 22-25 Eylül, Manavgat, Antalya, Tebliğ özetleri, s.241

7. Zoltan D (2003): Therapeutic aspects of elbow dysplasia, Köpeklerde Gelişimsel Kalça ve Dirsek Displazisi Kursu ve Workshop'1, Anküsem, 23-25 Mayıs, Ankara, s.20-30

Geliş tarihi: 28.12.2005 / Kabul tarihi: 05.01.2006

\section{Yazışma Adresi:}

Arş. Gör. Cenk Yardımcı

Ankara Üniversitesi Veteriner Fakültesi

Cerrahi Anabilim Dalı, 06110

Dışkapı / Ankara 


\title{
Short Communication / Kısa Bilimsel Çalışma
}

\section{Serodiagnosis of bovine neosporosis with immunocomb assay in Ankara region}

\author{
Arif KURTDEDE ${ }^{1}$, Şükrü KÜPLÜLÜ ${ }^{2}$, Kerem URAL $^{1}$, C. Çağrı CINGI ${ }^{1}$, Murat GÜZEL ${ }^{3}$, \\ M. Çağrı KARAKURUM ${ }^{1}$, A. Evren HAYDARDEDEOĞLU ${ }^{1}$
}

\author{
${ }^{1}$ Department of Internal Medicine, ${ }^{2}$ Department of Gynaecology and Obstetrics, Faculty of Veterinary Medicine, \\ University of Ankara; ${ }^{3}$ Department of Internal Medicine, Faculty of Veterinary Medicine, University of Mustafa Kemal, Hatay
}

\begin{abstract}
Summary: Serodiagnosis of bovine neosporosis in 60 cows in Ankara was evaluated by a commercially produced solid phased immunoassay principle, immunocomb. Serum samples were taken from aborted $(n=12)$ and non-aborted ( $n=48)$ cows in three different locations of Ankara. Six out of 12 aborted cows (50\%) were seropositive by immunocomb (IC) assay indicated that neosporosis may be an important cause of abortions in this region. In conclusion, as a practical note, the IC assay was very simple, easy and quick to use for serological testing and screening of neosporosis both for large and small volume of herds.
\end{abstract}

Key words: Neosporosis, immuncomb, cattle, Turkey.

\section{Ankara yöresinde sığır neosporozisinin immunocomb testi ile serolojik tanısı}

Özet: Ankara'da 60 sığırda neosporozis'in serodiyagnozu ticari olarak üretilmiş katı fazlı immunoassay prensibi ile çalışan immunocomb (IC) ile belirlendi. Serum örnekleri Ankara'nın üç farklı bölgesinde abort yapmış ( $\mathrm{n}=12)$ ve abort yapmamış ( $\mathrm{n}=48)$ ineklerden alındı. Abort yapmış 12 inekten 6'sında (\% 50) IC ile belirlenen seropozitivite neosporozis'in bu bölgedeki abortların önemli bir nedeni olabileceğini gösterdi. Sonuç olarak pratikte, IC'nin oldukça basit, kolay ve kısa sürede seri serolojik kontroller için ve gerek büyük gerekse küçük sürülerde neosporozis'in montorizasyonu için kullanılabileceği kanısına varıldı.

Anahtar sözcükler: Neosporozis, immuncomb, sığır, Türkiye.

Neospora caninum (N. caninum) infection, recognized as one of the most important cause of abortion in dairy cattle, has been reported as the cause of abortion and therefore neonatal mortality (8). Economic loss associated with $N$. caninum infection is because of increased prevalence of abortions and decreased milk and meat production in infected animals $(3,13)$.

The objective of the present study was to survey aborted and non-aborted cattle in Ankara to determine the serodiagnosis of $N$. caninum by immunocomb.

In the present study the serodiagnosis of N.caninum in 60 cows in three locations of Ankara were tested by commercially available Neospora Ab test kit (Bovine Neospora Ab test kit; Immunocomb).

\section{Study site and blood sampling}

The present study was conducted in Ankara. Convenience samples were collected from cows in three locations.

Blood samples were obtained from 60 cows over a period of 4 months. Fourtyeight of the 60 cows had no history of abortion while the remaining 12 were aborted previously. Information on the aborted cows $(n=12)$ is given in Table 1. Samples from non-aborting cows were randomly selected.

Table 1. The presence of antibodies to N.caninum on the aborted cows $(\mathrm{n}=12)$ in Ankara.

Tablo 1. Ankara'da abort yapan sığırlarda $(\mathrm{n}=12) N$. caninum antikorlarının varlı̆̆

\begin{tabular}{ccccc}
\hline No & $\begin{array}{c}\text { Age } \\
\text { (years) }\end{array}$ & $\begin{array}{c}\text { Abortion time } \\
\text { (during } \\
\text { gestation } \\
\text { months) }\end{array}$ & $\begin{array}{c}\text { No of } \\
\text { aborts } \\
\text { recorded }\end{array}$ & $\begin{array}{c}\text { N.caninum } \\
\text { antibody titer } \\
\text { detected within } \\
\text { immunocomb) }\end{array}$ \\
\hline 1. & 6 & 8 & First & - \\
2. & 5 & 6 & First & - \\
3. & 4 & 4 & First & High \\
4. & 6 & 4 & Second & High \\
5. & 2 & 5.5 & First & - \\
6. & 4 & 5 & First & Medium \\
7. & 3 & 5 & First & Medium \\
8. & 4 & 8 & First & High \\
9. & 5 & 4 & First & - \\
10. & 2 & 6 & First & Medium \\
11 & 5 & 2 & First & - \\
12. & 5 & 6 & First & - \\
\hline
\end{tabular}




\section{Immunocomb analysis}

The IC assay was performed according to the manufacturer's instructions, including the color development, and the evaluation and interpretation of the results, independently. Before reading and interpretation of the results the immunocomb was air dried and aligned with the calibrated color combscale. Positive and negative control sera, provided by the manufacturer (Biogal), were used in each test and the color resulting from the positive control sample $(\mathrm{C}+)$ was taken into comparison within the calibrated color combscale. Finally the most appropriate color was selected and the titre was evaluated for each sample. Samples with an identical or higher color intensity than the positive control $(\mathrm{C}+)$ were considered to have positive reaction for Neospora (High positive, positive, medium positive) (Table 1).

Of the 60 cows tested by the IC system 6 cows (10\%) were seropositive to N.caninum. Seropositive cows $(n=6)$ were found on two locations and all of them were aborted (Table 1). Neospora caninum antibodies were not detected in the non-aborted cows $(n=48)$.

Neosporosis has emerged as an important disease of cattle within the primary, and only sign observed in adult cows, clinical sign of abortion especially occuring during the middle of gestation $(1,7)$. Cows of any age may have abortion from 3 months of gestation to term, mostly at 56 months of gestation (1). In agreement with the latter report, affected cows in the present study had the abortion time of $4(\mathrm{no}=3$ and $\mathrm{no}=4), 5(\mathrm{no}=6$ and $\mathrm{no}=7)$, $6(n o=10)$ and $8(n o=8)$ months of gestation respectively.

Two major route has been reported for the transmission of $N$. caninum, either by horizontal postnatal infection through a definitive host, probably a canid, or by vertically from an infected dam to the foetus $(1,9)$. At recently although canids status of being definitive hosts for $N$. caninum remains unclear (7), several epidemiological studies suggested dogs' role in the transmission of neosporosis $(4,11,14)$.

Susceptible hosts, although only have been reported experimentally in mice, may be infected by ingesting food and water contaminated with $N$. caninum oocysts by dog feces (10). Thus in the present study as being informed by the owners, the fodder and drinking water in the resting field of the cows could be contaminated with N.caninum oocysts by the neighbouring dogs.

In a previous seroepidemiological study in dogs and cattle, 36 dogs out of $152(23.6 \%)$, from dairy farms with a known prevalence of $N$. caninum antibodies in the cattle, were seropositive to $N$. caninum, suggesting the relationship between $N$. caninum infection of farm dogs and cattle (14). Similar observation has been reported by Dijkstra and others (6) in a previous study hypothesizing that a newly introduced dog infected with $N$. caninum from already infected cattle, transmitted the infection to other cattle within shedding of oocysts.

In the diagnosis of bovine neospora infection a veterinary diagnostic laboratory assitance is required. At present two major types of serological testing, indirect fluorescent antibody test (IFAT) and enzyme-linked immunosorbent assay (ELISA), have been widely used. However there are a variety of different procedures in order to carry out these tests, in which most of them are based on the usage of culture-derivated tachyzoites of $N$. caninum bovine or canine isolates (1). Careful consideration must be given to use and evaluation of serologic results, particularly in order to establish appropriate cut-of titers for each test. A definitive cut-off titer for serodiagnostic survey has not been settled for bovine neosporosis because of lack of certainty of serological diagnosis for chronically infected cattle and therefore the limited knowledge from noninfected cattle $(1,7)$.

In Tekirdağ and Kırklareli, Trakya region in Turkey, a seroprevalence study using an ELISA in cattle showed that 7 out of $124(5.6 \%)$ and 15 out of 150 (10 $\%)$ animals in Tekirdağ and Kirklareli respectively, had antibodies against $N$. caninum (5). In another seroprevalence study in Sanliurfa province, southeast part of Turkey, 23 cattle $(7.5 \%)$ out of 305 were found to be positive against $N$. caninum antibodies (12).

In recent years, a commercially available immunocomb (IC) system (Immunocomb bovine Neospora antibody test kit; Biogal) has been designed and developed for the determination of cow serum $\mathrm{IgG}$ antibody titers for $N$. caninum. This assay is based on a solid phased immunoassay principle, that is attached within purified $N$. caninum antigen. The present test is very simple, reliable and quick, that the results can be obtained in 40 minutes. The rapid results in kit format, that the test provides, is appropriate for laboratory and field use, especially for serological screening of herds (2).

IC system allows producers for testing animals against neosporosis before breeding selection and/or prior to purchasing as for indicating the infection status. As an example of where the IC system used was a 150 cow dairy herd that Dr. Landmann, from Tick Fever Research Centre-Queensland Australia, recently dealt with, where as $24 \%$ of the animals were infected with $N$. caninum. In regard to the latter researcher, the IC system is a valuable tool that is helpful for the exclusion of neosporosis and he recommend this assay in various countries (2).

The observation that 6 out of 12 aborted cows $(50 \%)$ in Ankara were seropositive by immunocomb (IC) 
system indicated that neosporosis may be an important cause of abortions in this region. Although neosporosis has been recently reported in Turkey, these data give a preliminary indication of the prevalence of infection in the cattle population in Ankara, Turkey. Further studies are necessary to investigate the seroprevalence in other regions, and the possible association between seropositive animals and bovine abortions.

Finally, as a practical note, especially for the serological testing and for screening of both the large and small volume of herds, the IC assay was very simple, quick and reliable. However reading of the IC assay results is done by eye, which may cause misinterpretations, it is always necessary to evaluate the results by two or more independent well qualified operatives. Furthermore larger, long-term investigations are necessary to evaluate immunucomb in comparison to other tests (e.i. ELISA, IFAT) for the diagnosis of neosporosis in Ankara, Turkey.

\section{References}

1. Anderson ML, Andrianarivo AG, Conrad PA (2000): Neosporosis in cattle. Anim Reprod Sci, 60-61, 417-431.

2. Anonymous (2005): available at http:/www.biogal.co.il. communication date: 23.08.2005

3. Barling KS, McNeil JW, Trompson JA (2002): Association of serologic status for Neospora caninum with postweaning weight gain and carcass measurements in breef calves. J Am Vet Med Assoc, 217, 1356-1360.

4. Bartels CJM, Wuonda W, Schukken YH (1999): Risk factor for Neospora caninum-associated abortion storms in dairy herds in the Netherlands (1995 to 1997). Theriogenology, 52, 247-257.

5. Bıyıkoğlu G, Öncel T, Bağcı O (2003).: Trakya sığırlarinda Neospora caninum'un seroprevalanst. XIII.Ulusal Parazitoloji Kongresi, 8-12 Eylül 2003, Konya, Turkey.
6. Dijkstra Th, Barkema HW, Hesselink JW, Wouda W (2002): Point source exposure of cattle to Neospora caninum consistent with periods of common housing and feeding and related to the introduction of a dog. Vet Parasitol, 105, 89-98.

7. Dubey JP (1999): Recent advances in Neospora and neosporosis. Vet Parasitol, 84, 349-367.

8. Dubey JP, Lindsay DS (1996): A review of Neospora caninum and neosporosis. Vet. Parasitol, 67, 1-59.

9. Landmann JK, Jillelle D, O'Donoghue PJ, McGowan MR (2002): Confirmation of the prevention of vertical taransmission of Neospora caninum in cattle by the use of embryo transfer. Aust Vet J, 80, 502-503.

10. McAllister MM, Jolley WR, Wills RA, Lindsay DS, McGuire AM, Tranas JD (1998): Oral inoculation of cats with tissue cysts of Neospora caninum. Am J Vet Res, 59, 441-444.

11. Paré J, Fecteau G, Fortin M, Marsolais G (1998): Seroepidemiologic study of N.caninum in dairy herds. JAVMA, 213, 1595-1598.

12. Sevgili M, Altas MG, Keskin O (2003): Şanluurfa yöresinde sığırlarda Neospora caninum'un seroprevalansı. XIII.Ulusal Parazitoloji Kongresi, 8-12 Eylül 2003, Konya, Turkey.

13. Thurmond MC, Hietala SK (1997): Effect of Neospora caninum infection on milk production of first-lactation dairy cows. JAVMA, 210, 672-674.

14. Wouda W, Dijkstra Th, Kramer AHM, Maanen Cvan, Brinkhof JMA (1999): Seroepidemiological evidence for a relationship between Neospora caninum infections in dogs and cattle. Int J Parasitol, 29, 1677-1682.

Geliş tarihi: 08.11.2005 / Kabul tarihi: 23.12.2005
Address for correspondence
Prof. Dr. Arif Kurtdede
Ankara Universitesi
Veteriner Fakültesi
Iç Hastalıkları ABD,
Dişkapl-Ankara 06110 Türkiye 